\title{
The Middle Ages of Postmodernism: Dante, Thom Yorke and Radiohead
}

\author{
Giulio Carlo Pantalei \\ Università Roma 3 \\ giuliopantalei@gmail.com \\ https://orcid.org/0000-0002-5105-2527
}

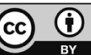

\begin{abstract}
The relationship between Dante and Radiohead has been intense and surprisingly enduring through the years: from the conceptual framework of OK Computer (1997) to the experimentalism of Amnesiac (200I), taking into account the Dolce Stil Novo motifs within In Rainbows (2007). The survey will try to retrace the imaginarium of the songwriter within the literary land of the Florentine Poet, exploring the thresholds and paratexts used to convey a modernization of the Commedia. An original interpretation of some among Radiohead's most acclaimed works, including $2+2=5$ (The Lukewarm - Gli Ignavi) and Pyramid Song, will reveal the depth -also philogical and intertextual- of this cultural operation that ranges from the social commitment of the Sommo Poeta to a superhuman journey to Heaven «in a little rowboat» through a special guide which leads to Love in itself.
\end{abstract}

Key Words: Dante Alighieri; Radiohead; Thom Yorke; Divina Commedia; Rachel Owen; English translations of the Divine Comedy.

\section{Riassunto}

Il rapporto tra Dante e Radiohead è stato intenso e sorprendentemente duraturo nel corso degli anni: dal quadro concettuale di OK Computer (1997) allo sperimentalismo di Amnesiac (200I), tenendo conto dei motivi di Dolce Stil Novo in In Rainbows (2007). L'indagine cercherà di ripercorrere l'immaginario del cantautore all'interno della terra letteraria del poeta fiorentino, esplorando le soglie e i paratesti utilizzati per trasmettere una modernizzazione della Commedia. Un'originale interpretazione di alcune tra le opere più acclamate di Radiohead, tra cui $2+2=5$ (The Lukewarm - Gli Ignavi) e Pyramid Song, svelerà la profondità -anche filogica e intertestuale- di questa operazione culturale che spazia dall'impegno sociale del Sommo Poeta a un sovrumano viaggio verso il Cielo "in una piccola barca a remi" attraverso una guida speciale che conduce all'Amore in sé.

Parole chiave: Dante Alighieri; Radiohead; Thom Yorke; Divina Commedia; Rachel Owen; traduzioni in inglese della Divina Commedia. 
To the loving memory of Dr Rachel Owen, to what she inspired

\section{I. "Forse tU NON PENSAVI CH'IO LÖICO FOSSI!": THE LITERATURE BEHIND THE MUSIC}

Tf Dante carved out through poetry a new space where everyone can find "what was, what is and what will be, the history of the Past and the history of the Future, all the things that I had and I will have, since everything of this is expecting us in some part of his quiet labyrinth" (Borges 200I, prologue), it could be arguable to say that Radiohead did something similar to Rock music at the end of the $20^{\text {th }}$ Century, embracing all the traditions behind them from Classical music to Blues, from Jazz to Electronic - and conveying it to somewhere new, a Post-, towards the Computer and PDA-based existence of our present age.

Since each and every work of art that brings about a major cultural transformation requires both a conscious and an archetypical knowledge of its time and of what came before its time, a cultural operation like the one planned by Radiohead demanded an appropriate interest and competence in literature, art, spirituality, politics, cinema and graphics, highbrow and lowbrow culture, social commitment, counterculture and all the possible bends of the humanities, as the consubstantial content of their own music. Gianfranco Franchi, that studied and interpreted the lyrics of the band from cover to cover, summed it up this way:

Oxford. The Nineties. A young student of Literature decides to go down in Rock and Roll History by writing, along with his fellows, the soundtrack to the twilight of the Western Society [...]. He talks very often about the music, the movies and the books that he loved. Sometimes, he conceals them in his lyrics: and real fans get crazy to find out these sources. And so, Douglas Adams, Thomas Pynchon, Lewis Carroll, George Orwell, Thomas Stearns Eliot, Kurt Vonnegut, Goethe and Dante smoothly adjust to Rock songwriting. Everything in its right place. (Franchi 2009, I3)

What could probably strike most is to know that, on closer inspection, all the members of the band actually possessed an in-depth education within the humanities: indeed, not everyone knows that before becoming widely known as musicians, Radiohead were a group of aspiring Literature scholars. Thom Yorke, the eclectic leader of the band, studied English Literature at the University of Exeter; the bass player Colin Greenwood attended the classes of "Modern American Literature" at Peterhouse College in Cambridge; drummer Philip Selway specialized in Literature and History at John 
Moores University in Liverpool, working then as an English teacher for some years; guitarist Jonny Greenwood started a Master in Music and Literature at Brookes University in Oxford (Randall 2000, 43). Therefore, it is inevitable to find a profound literary filigree within the lyrics of their songs, from Pablo Honey (1993) to A Moon Shaped Pool (2016), through an intricate net of quotations and textual references by using in an interesting way, probably at their most, the thresholds and paratexts that visually and materially came out with their releases or the advertising related to them, suffice it to mention the pioneering use of the Internet between the late 90s and the early 2000 s as logbook for their recordings.

Undoubtedly close to the English Dystopian and Sci-Fi tradition which ranges from Aldous Huxley and George Orwell to James G. Ballard, the band's imaginarium is indeed populated with humanized computers and computerized humans, plastic realities and substance that lies under the surface, sycophants and people corrupted by power and greed, where each individual resists and fights against everyday alienation and conformism through the subversive truth of the feelings. Nevertheless, even though the Science Fiction field seems to constitute the main interpretative key to Radiohead, the literary path hyperbolically swerves to the Italian Middle ages, similarly to the unexpected modulation shifts within one of their tunes.

\section{True Love Waits: the INFERNO BeHINd OK COMPUTER AND KID A, THE STILNOVO OF IN RAINBOWS}

Opening their Website home page during the Kid A (2000) era, the audience would have found a peculiar and mysterious quotation, embedded into the foreground of a gloomy beautiful artwork made up of sharp-cornered dark woods, ice-coloured mountains, collapsing new buildings and blood-red bottomless pits:

\section{repeat parrot fashion}

now must thou cast off all sloth.... for sitting on down or under blankets none comes to fame, and without it he that consumes his life leaves no trace of himself on earth, as smoke in air or foam on the water. rise, therefore, conquer thy distress with the soul, which conquers in every battle if it does not sink with its body's weight. there is a longer stair which must be climbed.

By clicking on the stanza, all of a sudden, a string could have been revealed and this string showed, of course, "Dante, Commedia, Inferno XXIV, 46-55" (Radiohead Archive, 2000). Through the display of the source, it gets clear that Radiohead used those verses to constitute a possible hypotext, using a 
Genette nomenclature, that offered the audience the chance to figure out the inspiration behind the lyrical, visual and conceptual imaginarium of their new work. Indeed, the tercets were drawn by the attentive Charles S. Singleton's translation of the Divine Comedy (Alighieri 1971, 249) edited and published in 1970, "considered perhaps the most scholarly, with separate volumes for notes, and (which) eschewed the poetic form altogether for a painstakingly literal prose translation" (Schemo 1995), referring to the passage in which Virgil admonishes Dante who is resting for a while after the climbing from Malebolge:

"Omai convien che tu così ti spoltre", disse 'l maestro; "ché, seggendo in piuma, in fama non si vien, né sotto coltre;

sanza la qual chi sua vita consuma, cotal vestigio in terra di sé lascia, qual fummo in aere e in acqua la schiuma.

E però leva sù; vinci l'ambascia con l'animo che vince ogne battaglia, se col suo grave corpo non s'accascia.

Più lunga scala convien che si saglia; non basta da costoro esser partito.

Se tu mi 'ntendi, or fa sì che ti vaglia". $(\text { If., XXIV, } 46-55)^{\mathrm{I}}$

The epigraphic value that these quoted words own for the entire record definitely put up a question, that is how the band got so familiar with the Sommo Poeta and what was the first time they decided to elect the Father of the Italian Literature as one of the main characters of their Postmodern imaginarium. As a matter of fact, a deeper glance at Radiohead's Website archive unveils an interesting clue from 1997, during the groundbreaking Ok Computer (1997) recording sessions, which reported: "polyethelene* will never break down swirly self announcements. stuck in a frozen lake. the penultimate place in dante's hell" (Radiohead Archive 1997). In addition to this, the title for the whole page was "Stuck in a frozen lake", referring to vv, $16-24$ of the XXXII Canto of Dante's Inferno, particularly akin to the band's reading if compared to the verse translation into English by Allen Mandelbaum first published between I980 and 1984 , from whom the sentence "stuck in a frozen lake" (v. 23) seems to be taken:

When we were right down in that dark well, Below the giant's feet, and much lower, And I was still staring at the high wall,

I heard someone say: "Take care how you go by;

I. The quotes taken from the original text will follow for the whole article the edition edited and commented by Anna Maria Chiavacci Leonardi (Bologna: Zanichelli 200I). 
Walk so as not to trample on the heads

Of brothers who are wretched and exhausted."

And so I turned round, and saw before me

And below my feet, a lake, which was frozen

Till it had more the look of glass than water.

(Alighieri 1998, I82)

Come noi fummo giù nel pozzo scuro

sotto i piè del gigante assai più bassi,

e io mirava ancora a l'alto muro,

dicere udimi: "Guarda come passi:

va sì, che tu non calchi con le piante

le teste de' fratei miseri lassi".

Per ch'io mi volsi, e vidimi davante

e sotto i piedi un lago che per gelo

avea di vetro e non d'acqua sembiante.

(If., XXXII, I6-24)

The passage, in particular, that describes Dante and Virgil arriving at the Ninth Circle of Hell allocated to the guilty of treachery against their own beloved immersed in the river Cocytus, is mentioned as reference for a song called Polyethylene, which eventually came out as a B-side of Paranoid Android. A swift glimpse of the lyrics, expressionistically-dyed as usual in the 9os aesthetics, shows the peculiar present-value factor that connects Dante's conception of betrayal to our age, that is - in step with the whole narration of Ok Computer, suffice it to think about No Surprises that works as a mission statement in this regard - to betray our own selves and give up our deepest passions, our dreams, in order to accept the conformism of the "plastic middle class" and live a flat and dull bourgeoise life, as the commonest modern way to sell our souls:

POLYETHYLENE

So sell your suit and tie

And come and live with me

Leukemia schizophrenia

Polyethylene

There is no significant risk to your health

She used to be beautiful lumps and swell.

Plastic bag, middle class

Polyethylene

Decaffeinate, unleaded

Keep all surfaces clean

If you don't believe this, sell your soul

If you don't get into it, no one will

(Radiohead 1997) 
As the entrance to Hell could seem etched with the words "Lasciate ogni speranza, voi ch'entrate" in Contemporary times, on the contrary, this literary path will prove that there is always one hope to cling to. This hope, as in Dante, is love and it leads to a definitely longer stair to be climbed. Indeed, even though the highbrow education of the band members acts as the primary substratum for the wide and eclectic spectrum of cultural references for the imaginarium, it must be said that there is also a modern Dolce Stil Novo love story behind this surprising relationship between Dante and Radiohead. Indeed, the main duct for the presence of the Sommo Poeta was probably Rachel Owen, long-time partner of Thom Yorke, esteemed avant-garde artist and, most of all, appreciated scholar majored in Italian Middle Ages and Dante Studies, who studied thoroughly the illuminated manuscripts of the Commedia:

«Scelsi di studiare all'Accademia di Belle Arti a Firenze. E fu un'ottima scelta». Qui Rachel si innamorò di Dante: le illustrazioni della Commedia sarebbero diventate la materia del suo $\mathrm{PhD}$ all'Università di Exeter («e questo mi riportò a Firenze, e in Italia, dove frequentai le maggiori biblioteche; anch'io, tra l'altro, ho realizzato una serie di incisioni per il poema») [...] «Evidentemente, dopo tanti anni, sono riuscita a contagiare Thom almeno in questo». (Paloscia and Owen 20I2)

It seems now clear that Yorke's special empathy with Dante derives from a beautiful and profound source, that is the transposition of an inner personal passion to a broader scale through music and art. Quite fascinating, in this regard, the theory proposed by Emanuele Binelli Mantelli, who first put near each other some metaphors and images recalled by the lyrics of In Rainbows

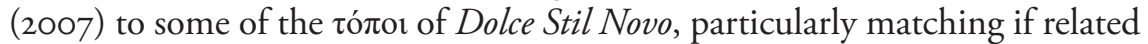
to the sense of sight and the ocular sphere, that bring to mind and renew the legacy of poems as Veggio negli occhi della donna mia by Guido Cavalcanti or Ne li occhi porta la mia donna Amore by Dante himself with "well-connoted verses and words as the ones in Weird Fishes/Arpeggi" (Binelli Mantelli 20I4):

In the deepest ocean

The bottom of the sea

Your eyes

They turn me

Turn me on to phantoms

I follow to the edge of the earth

and fall off

(Yorke 2007)

In my lady's eyes I see a light filled with such spirits of Love it brings my heart new hope of 
being once more inspired to life.

(Cavalcanti 2009, 43)

Veggio negli occhi de la donna mia un lume pien di spiriti d'amore, che porta uno piacer novo nel core, sì che vi desta d'allegrezza vita.

Thus, under the intersection between Dante and Radiohead lies a true love story, it is better to stake this claim right from the start; and the next paragraphs will delve deeper into the philological measure of this human and literary bond.

\section{Big Brother IS WATCHING YOU: $2+2=5$ (THE LUKEWARM - GLI IGNAVI)}

Between 2002 and 2003 the United States of America and the United Kingdom gathered a military coalition to invade Iraq and Afghanistan, giving birth to two among the harshest conflicts in the recent past. Radiohead publicly lined up against this self-absorbed war disguised as a peacekeeping mission and firmly criticized the American neo-con policies led by George W. Bush, to whom they addressed their critically-acclaimed sixth studio album called Hail to the Thief (2003). The title, which refers to the manipulated electoral victory of the $43^{\text {rd }}$ president of the US, foreshadows the social commitment behind the whole record and press charges against the entertainingly-supposed "shock and awe" live TV broadcasting as if in reality shows, calling to mind apocalyptic visions of the near future. For this reason, the opening track appears as a manifesto for the whole lyrical impact of the record and it is possible to figure out its value from the title itself, that is, $2+2=5$ (The Lukewarm), whose first section is a clear loan from George Orwell's dystopian masterpiece 1984: specifically, it evokes the final chapter of the novel, where the protagonist Winston Smith desperately acknowledges the impossibility of defeating the totalitarism of "the Party" after being tortured and brainwashed:

He could not fight against the Party any longer [...]. It was merely a question of learning to think as they thought. Only! The pencil felt thick and awkward in his fingers. He began to write down the thoughts that came into his head. He wrote first in large clumsy capitals: FREEDOM IS SLAVERY. Then almost without a pause he wrote beneath it: TWO AND TWO MAKE FIVE. (Orwell I990, 289)

By applying this Orwellian formula to the live-on-television Iraq and Afghanistan war, Yorke seems to state that the average viewer, somehow passive and hypnotized by cruelty, is ready to store every message and TV slogan supinely 
and without any critical thinking, whether it is "war is peacekeeping" or "two plus two equals five".

What could strike most, however, concerns the interpretation of the subtitle, that is "The Lukewarm" and this is the clue leading to the Sommo Poeta. Indeed, as explained by Yorke, Dante represents the inspiration and the source of this reference, namely the III Canto of the Inferno, in which the guilty of sloth are punished in the Antinferno. Sure enough, these damned souls are neither allowed into Heaven nor into Hell and they undergo one among the most truculent contrapassi of the First Cantica, forever condemned to run naked after a fleeting flag and continuously stung by wasps and horseflies while their dripping blood mixed with tears assembles a muddy puddle that feeds the "fastidiosi vermi" at their feet. This will be the pain, Yorke seems to warn, for those who will not take a position on this loss of humanity, restricting themselves to sit and watch bombings and deaths on TV; on the other side, the English artist ideally puts aside an equally severe punishment for the modern lords of war who perpetrate this top-down mystification, that is to be stuck in the frozen river of Cocytus within the Tolomea (a recurring element, as we could read in the previous paragraph about Polyethylene and the Caina). The peculiarity about these cursed people lies indeed in the fact that their soul sinks into Hell right at the moment in which they carry out the betrayal and their body, still on Earth, makes room for a demon that actually possesses their persona. Yorke himself gave a more detailed explanation about this conception:

If the motivation for naming our album had been based solely on the U.S. election, I'd find that to be pretty shallow, [...] To me, it's about forces that aren't necessarily human, forces that are creating this climate of fear. While making this record, I became obsessed with how certain people are able to inflict incredible pain on others while believing they're doing the right thing. They're taking people's souls from them before they're even dead. My girlfriend-she's a Dante expert-told me that was Dante's theory about traitors and authority. I was just overcome with all this fear and darkness. And that fear is the 'thief'. (Yorke 2003, Spin)

Therefore, the subtitle "lukewarm" appears to be the most appropriate epithet in order to describe the situation in which the modern political systems - through conniving mass media - desires to keep all the citizens who do not inform themselves and react to the current state of affairs; and, of course, this particular word is a Dantesque tribute, as pointed out by Yorke himself: "They, the indecisive, have done nothing wrong, they simply didn't do anything at all. So, Dante judges them and put them outside Heaven and Hell, and this - I guess - is one of the best ways to explain the concept of $2+2=5$ " (Yorke 2003, XFM). Besides this fact, a consideration must be done 
concerning the unique lexical choice: indeed, the grand adjective "lukewarm" seems to be present as a description note only, and not by chance due to Yorke's residence, in the Manuscript Holkham Misc. 48 kept by the Bodleian Library at the University of Oxford, a description in English written by the modern Oxonian curators of the manuscript (Bodleian Library 2000). Nevertheless, it is always the lyrics to hold the most interesting legacy with the Divine Comedy:

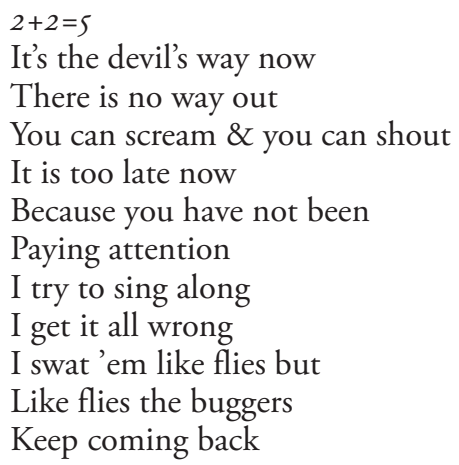

Indeed, the image of the insects seems to draw fully from Dante's contrapasso in the III Canto (vv. 64-69) of Inferno and upon closer inspection it echoes back to a particular translation into English of the poem, scilicet the one made by Robert M. Torrance, that seems even to hold a sort of intertextual relationship with these lyrics:

These wretches, who had never been alive ran naked, stimulated by the prick of flies, and hornets swarming from the hive

Blood streaked their countenances, clotting thick, till, mixed with tears, it trickled to their feet, where nauseating worms could take their pick (Alighieri 20II, 5I)

Questi sciaurati, che mai non fur vivi, erano ignudi e stimolati molto da mosconi e da vespe ch'eran ivi.

Elle rigavan lor di sangue il volto, che, mischiato di lagrime, a' lor piedi da fastidiosi vermi era ricolto.

(If., III, 64-69)

In conclusion, the verse "It's the devil's way now" ultimately marks Yorke's modernization of the Poema Sacro gathering themes that are dear to the Florentine poet in an Orwellian declension: the threat of totalitarianism, the 
atrocity of modern warfare and the sloth of the masses produces monsters, and this is the Devil's way to make it happen nowadays. Yorke basically invites everyone to be careful and take an active part in her or his day and age, for being responsible citizens and never lukewarm, which is something very close to what Antonio Gramsci, one of the greatest Italian political and philosophical minds of the $20^{\text {th }}$ century, wrote in his famous manifesto against sloth and indolence, probably known by the band as retraced by their Italian biographer (Franchi 2006):

Odio gli indifferenti. Chi vive veramente non può non essere cittadino, e parteggiare. Indifferenza è abulia, è parassitismo, è vigliaccheria, non è vita. Perciò odio gli indifferenti. L'indifferenza è il peso morto della storia. L'indifferenza opera potentemente nella storia. Opera passivamente, ma opera. È la fatalità; è ciò su cui non si può contare; è ciò che sconvolge i programmi, che rovescia i piani meglio costruiti; è la materia bruta che strozza l'intelligenza. [...] Vivo, sono partigiano. Perciò odio chi non parteggia, odio gli indifferenti. (Gramsci 1917)

\section{LOVE WHICH MOVES THE SUN AND THE OTHER STARS: PYRAMID SONG}

Unlike most of American and English music artists of the past Century, that especially focused on Dante's first Cantica, Thom Yorke proved to delve deeper into the Italian poetic masterpiece, and particularly in one of Radiohead's most celebrated songs, whose name is Pyramid Song, he seemed to step further on that pathway that leads to the oneiric and the superhuman. As a matter of fact, the orchestral composition, included in Amnesiac (200I), describes a transcendental trajectory and a spiritual journey through space and time that seems to allude to some motifs of the Commedia, and beyond, since the songwriter himself mentioned alongside Dante, the Tibetan Book of the Dead (Bardo Thodol), the Egyptian Book of the Dead, Herman Hesse's Siddharta and A Brief History of Time: From the Big Bang to Black Holes by Stephen Hawking as other main references (Green Plastic 200I). The beauty of the work actually succeeds in putting into music a kind of crasis for this whole spectrum of inspirations. Furthermore, in relation to the writing of the lyrics, Yorke said:

That song literally took five minutes to write, but yet it came from all these mad places. [It's] something I never thought I could actually get across in a song and lyrically. I managed it and that was really, really tough. Stephen Hawking talks about the theory that time is another force. It's a fourth dimension and he talks about the idea that time is completely cyclical, it's always doing this [spins finger]. It's a factor, like gravity. It's something that I found in Buddhism and Dante as well. That's what Pyramid Song' 
is about, the fact that everything is going in circles. (Yorke qtd. in Citizen Insane 2000)

The lyrics actually consists of only one stanza which is repeated with a mantra-like rhythmic cadence that rises as the strings crescendo moves upwards. Starting with the title, even though the main source is of course Egyptian in this sense, it is helpful to point out that the shape of the Pyramid is essential also in Dante's geography, based as widely-known on a Ptolemaic structure: indeed, both the chasm of Hell and the Mountain of Purgatorio are pyramids and, after all, the whole Itinerarium ad Deum marks a pyramidal ascension to a peak. A deep verse-by-verse comparison between the poem and the lyrics could establish an original Dante-oriented revelation about the song:

\section{I jumped in a river and what Did I see?}

The opening image depicts a katabasis, or rather, a real immersion in a mystical river, a ritualistic crossing that recalls a classic тó Dante: in particular, the Lethe river (Pg. XXXI, especially vv. 82-IO5), in which the Florentine poet must dive in in order to forget his sins before the elevation to Paradise.

\section{Black-eyed angels swam with me}

Demons, especially since the poet's entrance to the City of Dite of the VIII Canto on, follow Dante and Virgil along the descent to the bassi loci, and within the translation into English of the poem they are often called "the black angels", suffice it to mention Inferno XXIII, vv. I30-I32: "Through which both of us can get away / without encouraging the black angels / To come down to this place and get us out” ("Onde noi amendue possiamo uscirci / sanza costrigner de li angeli neri», Alighieri 2008). It is fascinating to reflect upon the lack of a religious metaphorical sense in Yorke's verses, something that could even enhance - assisted by music - some sensual and dreamlike features behind these "black-eyed angels".

A moon full of stars and astral cars

The lunar nocturne and the brightness of the stars could sound familiar to the translation into English of Inferno's last verses, in which Dante, turned upside down, leaves the kingdom of Hell and lands on the bay of Purgatorio passing through the natural burella: "And beauteous hinging of the Heavenly cars / And we walked out once more beneath the stars" ("Tanto ch'i vidi de le cose belle / che porta 'l ciel, per un pertugio tondo. / E quindi uscimmo a riveder le stelle", Alighieri 2009). Moreover, the rhyming couple "stars - cars" appears to be uncommon, not to say unique, within the English Language poetic tradition with the only exception of a poem by William B. Yeats in which however 
the word 'cars' means 'vehicles': "For Fergus rules the brazen cars / [...] and all dishevelled wandering stars" (Yeats 2000, 34).

All the figures that I used to see

The souls that Dante meets on the supernatural trail are often translated as "shades" or "figures" in order to instil their nature of immateriality. Taking into account a locus for each Cantica": "I gazed around a while and then looked down, / and by my feet I saw two figures clasped / so tight that one's hair could have been the other's" ("Quand'io m'ebbi dintorno alquanto visto, / volsimi a' piedi, e vidi due si' stretti, / che 'l pel del capo avieno insieme misto", If. XXXII, vv. 40-42); "Behind the dancing figures, three or four / there came two aged men, differently dressed" ("Appresso tutto il pertrattato nodo, vidi due vecchi in abito dispari», Pg. XXIX, vv. I33-I35); "Even so, in its glowing jubilance / that holy figure hid itself from me, and so enraptured wrapt» («Per più letizia sì mi si nascose / dentro al suo raggio la figura santa / e così chiusa chiusa mi rispuose», $P d$. V, vv. 136-138). About the meaning and temporal value of the construct "I used to see", the following sentence will try to clarify.

\section{All my lovers were with me}

All my past and futures

The idea that within an otherworldly kingdom there could lie the possibility of meeting again the beloved ones is without a doubt a tó $\pi$ os of Classical memory, suffice it to mention the myth of Orpheus and Eurydice or the Alcestis by Euripides. Nevertheless, definitely more peculiar could appear the following verse "All my past and future", that, as reported in the aforementioned interview, draws inspiration by the theories about time of Stephen Hawking, Buddhism and Dante. As a matter of fact, the Sommo Poeta's temporal conception dictates to all the damned souls the impossibility of knowing and seeing the Present time, but only to remember the Past and to foreshadow the Future. More in particular, the Canto in which this vision is best elucidated should be the $\mathrm{X}$ of Inferno, with the famous question made by Dante and the prophetical answer by Farinata degli Uberti (vv. 97-I05):

'From what I hear, it seems You see beforehand that which time will bring, But cannot know what happens in the present.'

'We see, like those with faulty vision, Things at a distance,' he replied, 'that much, For us, the mighty Ruler's light still shines.

When things draw near or happen now,

2. All the following quotations are drawn by Alighieri 1984, Musa translation. 
Our minds are useless. Without the words of others We ca know nothing of your human state.'

(Alighieri 2000, I9I)

«El par che voi veggiate, se ben odo, dinanzi quel che 'l tempo seco adduce, e nel presente tenete altro modo».

«Noi veggiam, come quei c’ha mala luce, le cose», disse, "che ne son lontano; cotanto ancor ne splende il sommo duce.

Quando s'appressano o son, tutto è vano

Nostro intelletto; e s'altri non ci apporta, nulla sapem di vostro stato umano» (If., X, 97-I05)

A similar view seems to be called to mind in Yorke's perspective, that, it is helpful to point it out again, is carried out through a laic significance and only through the lens of love in its spiritual, metaphorical and also physical character.

And we all went to Heaven in a little rowboat

This is, in my opinion, the most philologically relevant verse within the whole lyrics, from whom it is possible to enter and explore this Dantesque suggestion at its highest peak. Indeed, one among the most celebrated Oxonian translations into English of the Medieval masterpiece, and precisely in these following loci of Inferno VIII (v.I5) and Purgatorio I (v.I), presents some verses that seems to perfectly match the above-mentioned lyrics (Alighieri 196I): "No bowstring ever sent an arrow off / to run through air with such precipitation / as the little boat which at that moment I saw" "Corda non pinse mai da sé saetta / che sì corresse via per l'aere snella, / com'io vidi una nave piccioletta»). Again, at the beginning of the second Cantica, on the shore of the Ante-Purgatory: "To run on better water now, the little boat / of my wit now lifts her sails and leaves / away to stern that cruel stretch of sea” («Per correr miglior acque alza le vele / omai la navicella del mio ingegno, / che lascia dietro a sé mar sì crudele»). Therefore, the similarity between Radiohead's "little rowboat" and the "piccioletta barca" gets even more profound if compared to the incipit of the II Canto of Paradiso: "All you who in your wish / have followed thus far in your little boat / behind this ship that singing sails these waters" ( $\mathrm{O}$ voi che siete in piccioletta barca, / desiderosi d'ascoltar, seguiti / dietro al mio legno che cantando varca»). In conclusion, if completed with the previous hemistich "We all went to heaven", the ascensional trajectory that leads to the paradisiacal stage by a little boat seems too accurate and refined not to bring to mind Dante's journey, in order to reach a transcendental elevation - without any religious implication - and to go beyond space and time. 
There was nothing to fear, nothing to doubt

Once the summit is reached, the soul is infused with the purest tranquillity and an ultimate state of $\dot{\alpha} \tau \alpha \rho \alpha \xi i \alpha$, the complete unperturbedness ("nothing to fear") and the complete enlightenment ("nothing to doubt") as professed by the Epicureans and the Stoics, by Transcendental Meditation and, of course, by Dante. Like the Florentine poet is often reassured throughout the supernatural kingdoms by his guides and his lover - Virgil, Beatrice, Saint Lucy and Holy Mary -, the English artist seems reassured through the harmony of lyrics and music itself, moved by Love as the sun, the notes and the other stars.

MS. Holkham misc. 48 , p. 4

(c) Bodleian Library, University of Oxford

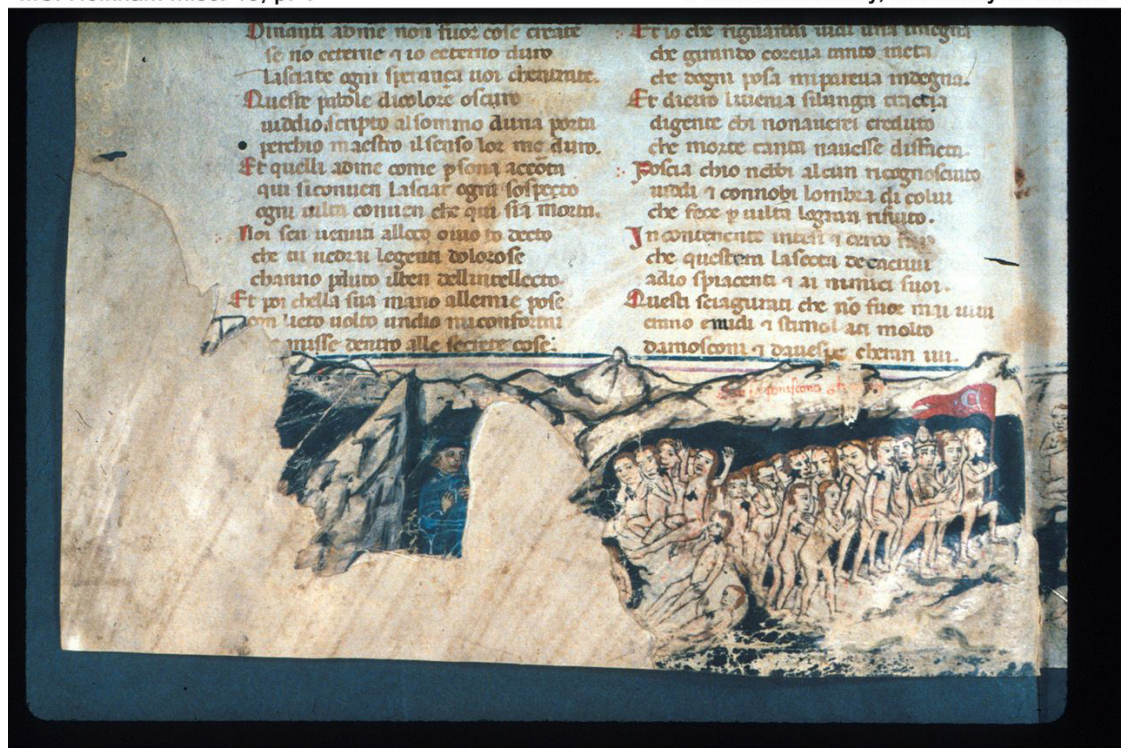




\section{Works Cited}

Alighieri, D. (196r). The Divine Comedy. 3: Paradiso. ed. and transl. John D. Sinclair. Oxford: Oxford University Press.

Alighieri, D. (1970). The Divine Comedy, Inferno, Vol. I: Italian Text and Translation. ed. and transl. Charles S. Singleton. London: Routledge Keagan.

Alighieri, D. (1984). The Divine Comedy: Inferno, Purgatory, Paradise ed. and transl. Mark Musa. London: Penguin Classics.

Alighieri, D. (1995). Dante's Inferno: The Indiana Critical Edition. ed. and transl. Mark Musa. Indiana: Indiana University Press.

Alighieri, D. (200o). The Inferno of Dante Alighieri. ed. and transl. Robert and Jean Hollander. New York: Anchor Books, Random House Inc.

Alighieri, D. (20or). Commedia. ed. and comm, Anna Maria Chiavacci Leonardi. Bologna: Zanichelli.

Alighieri, D. (2008). The Divine Comedy. ed. and transl. C. H. Sisson, Oxford: Oxford World's Classics.

Alighieri, D. (2009). The Inferno. ed. and transl. John Ciardi. New York: Signet Classics, Penguin Books USA.

Alighieri, D. (20II). Dante's Inferno, a New Translation in Terza Rima. ed. and transl. Robert M. Torrance. Xlibris Corporation: Bloomington $201 \mathrm{~s}$.

Binelli Mantelli, E. (20I4). Androidi, arcobaleni e fiori di loto. Le canzoni che hanno fatto la storia dei Radiohead. Roma: Arcana.

Borges, J. L. (200I). Nove saggi danteschi. Milano: Adelphi.

Cavalcanti, G. (2009). The Selected Poetry of Guido Cavalcanti: A Critical English Edition. Leicester: Troubador Publishing.

Citizen Insane. "Pyramid Song". < https://citizeninsane.eu/music/amnesiac/pyramidsong.html >. Last accessed January 27, 2019.

Franchi, G. (2009). Radiohead. A Kid. Testi commentati. Roma: Arcana.

Franchi, G. (2006, 26 February). "Radiohead - Kid A". Kult Underground. Num. 127.

Gramsci, A. (1917, II February). "Odio gli indifferenti". La città futura. .

Green Plastic. "Pyramid song / Egyptian Song Interpretation". < www.greenplastic. com/coldstorage/songinterp/eyptian song.html $>$. Last accessed January 2I, 2019.

MS. Holkham misc. 48, pp. I-54: Inferno. Oxford: Bodleian Library.

Orwell, George. (1990). I984. London: Penguin.

Owen, Rachel. (200I). "Dante's Reception by Fourteenth- and Fifteenth-Century Illustrators of the Commedia". Reading Medieval Studies. Num. 27.

Paloscia, F. and Owen R. "Rachel, l'altra artista di casa Yorke: «A Firenze mi innamorai di Dante»". La Repubblica: Firenze. 23 September, 2012.

Radiohead. (1997). OK Computer. Parlophone. London.

Radiohead. (2000). Kid A. Parlophone. London

Radiohead. (200I). Amnesiac. Parlophone. London.

Radiohead. (2003). Hail to the Thief. Parlophone. London.

Radiohead Official Archive. (I997). < http://archive.radiohead.com/SiteI/gallery. html $>$. Last accessed 27 January, 2019.

Radiohead Official Archive. (2000). < www.radiohead.com/Archive/Site7/prime8. $\underline{\mathrm{html}}>$. Last accessed June I5, 2015.

Randall, M. (2000). Exit Music: the Radiohead Story. Guildford: Delta.

Schemo, D. J. (I995, 3I January). "Bringing Dante Into the Realm of Contemporary English". The New York Times.. 
Spin. (2003, 29 June). "Fitter Happier: Radiohead Return. Interview with Thom Yorke”. < https://www.spin.com/2003/o6/fitter-happier-radiohead-return/ >. Last accessed January 27, 2019.

XFM Online. (2003, I3 July). "Thom Yorke on Hail To The Thief”. Last accessed June I5, 2015 .

Yeats, W. B. (200o). The Collected Poems of W. B. Yeats. Ware: Wordsworth Editions. 